have been due to direct trauma or haematoma around an aberrantly coursing hypoglossal nerve, we still consider high puncture of the internal jugular vein to be a useful approach.

We thank Mr F P Shabbo and Dr J E Brett for permission to report details of their patient.

' Scotti G, Melancon D, Olivier A. Hypoglossal paralysis due to compression by a tortuous internal carotid artery in the neck. Neuroradiology 1978; $14: 263-5$.

${ }^{2}$ Reichert W, Mehler D, Otten B. Isolated peripheral twelfth nerve paresis following puncture of the internal jugular vein. Anaesthetist $1981 ; 30$ : 46.

${ }^{3}$ Dehn TCB, Taylor GW. Cranial and cervical nerve damage associated with carotid endarterectomy. Br 7 Surg 1983;70:365-8.

' Agnoli A, Strauss P. Isolated paresis of the nervus hypoglossus and combined paresis of the nervus hypoglossus and the nervus lingualis following intubation and direct laryngoscopy. HNO 1970;18:237-9.

(Accepted 30 December 1983)

Regional Cardiothoracic Centre, Brook General Hospital, London SE18 21W

HEIKKI B WHITTET, MB, BS, senior house officer in cardiothoracic surgery

MICHAEL J BOSCOE, FFARCS, senior registrar in anaesthetics

Correspondence to: Dr H B Whittet.

\section{Persistence of rubella antibody 8-18 years after vaccination}

Immunity induced by rubella vaccines must persist throughout the childbearing years, a period of about 30 years. We have reported persistence of rubella antibody at values exceeding $15000 \mathrm{IU} / 1$ in $89.4 \%$ of volunteers vaccinated six to 16 years earlier. ${ }^{1}$ We now present the results of retesting these vaccinees two years later.

\section{Methods and results}

Serum samples were obtained between March and June 1983 from 93 of the 123 vaccinees previously tested. ${ }^{1}$ Sixty three volunteers had been vaccinated with RA27/3, HPV77-DE5, Cendehill, or a Japanese vaccine To-336 eight to 10 years previously while student nurses at St Thomas's Hospital, London. Thirty volunteers had been vaccinated with either RA27/3 or Cendehill vaccine 13-18 years previously while student nurses at The Hospital for Sick Children, London. Eight of these 93 vaccinees had low antibody values $(<15000 \mathrm{IU} / \mathrm{l})$ when tested in 1981 and were subsequently revaccinated with RA27/3 by the intranasal route. ${ }^{2}$

Sera were tested for rubella antibodies by single radial haemolysis ${ }^{3}$ and for rubella specific IgG by radioimmunoassay. ${ }^{4}$ Sera were compared with the standard serum containing 15000 IU rubella antibody per 1 , which is accepted as indicating a satisfactory level of immunity. ${ }^{3}$ Tests of significance were carried out using unpaired $t$ tests.

Of the 93 vaccinees tested, two were seronegative (no zone) by single radial haemolysis (table), although both had antibodies by radioimmunoassay (titres 20 and 320). One of these women had been among the group of eight with antibody values below $15000 \mathrm{IU} / 1$ who had been challenged with RA27/3 intranasally in 1981 . The remaining seven had antibody values exceeding $15000 \mathrm{IU} / 1$ by both single radial haemolysis and radioimmunoassay when tested two years after challenge. Eight to 10 years after vaccination the geometric mean titre of To-336 vaccinees measured by radioimmunoassay was higher than that of the other vaccine groups (table) but this difference was not significant $(p>0.05)$. Although volunteers given Cendehill vaccine 13-18 years previously had a lower geometric mean titre than those given the vaccine eight to 10 years before, this difference was not significant $(p>0.05)$. The two groups of RA27/3 vaccinees had a similar geometric mean titre.

\section{Comment}

We were reassured to find that antibodies ( $>15000 \mathrm{IU} / \mathrm{l})$ had persisted in most $(98 \%)$ of the rubella vaccinees eight to 18 years after vaccination. Nevertheless, in our previous study 13 of the 123 vaccinees $(10.6 \%)$ had antibody values below $15000 \mathrm{IU} / \mathrm{l}$, even when tested by radioimmunoassay. ${ }^{1}$

Of the two women with no antibody detectable by single radial haemolysis, one, who had a radioimmunoassay titre of $20(<15000$
Immune state and geometric mean antibody titres 8-18 years after rubella vaccination (that is, in 1983)

\begin{tabular}{|c|c|c|c|c|}
\hline \multirow{2}{*}{ Vaccine received } & \multirow{2}{*}{ No } & \multicolumn{2}{|c|}{$\begin{array}{l}\text { No }(\%) \text { with antibodies } \\
<15000 \mathrm{IU} / 1\end{array}$} & \multirow{2}{*}{$\underset{\text { RIA }}{\text { GMT }}$} \\
\hline & & SRH & RIA & \\
\hline \multicolumn{5}{|c|}{ Volunteers from St Thomas's Hospital vaccinated 8-10 years previously } \\
\hline RA27/3 & 26 & 0 & 0 & 1150 \\
\hline & 12 & & 0 & 1260 \\
\hline $\begin{array}{l}\text { HPV77-DE5 } \\
\text { TO- } 336\end{array}$ & 14 & $1(7 \cdot 1)$ & $\begin{array}{l}0 \\
0\end{array}$ & 1159 \\
\hline \multicolumn{5}{|c|}{$\begin{array}{l}\text { Volunteers from The Hospital for Sick Children } \\
\text { vaccinated } 13-18 \text { years previously }\end{array}$} \\
\hline $\begin{array}{l}\text { RA27/3 } \\
\text { Cendehill }\end{array}$ & $\begin{array}{l}12 \\
18\end{array}$ & ${ }_{0}^{1}(8 \cdot 3)$ & $1(8 \cdot 3)$ & $\begin{array}{r}1140 \\
746\end{array}$ \\
\hline Total vaccinees & 93 & $2(2 \cdot 1)$ & $1(1 \cdot 0)$ & 1180 \\
\hline
\end{tabular}

$\mathrm{SRH}=$ Single radial haemolysis. $\mathrm{RIA}=$ Radioimmunoassay. $\mathrm{GMT}=$ Geometric mean titre.

IU/1), had received RA27/3 13 years previously. This woman had had antibody values below $15000 \mathrm{IU} / 1$ by both single radial haemolysis and radioimmunoassay when tested in 1981; she was not revaccinated at that time as she was planning pregnancy. The other woman who was seronegative by single radial haemolysis had a radioimmunoassay titre of 320 (>15000 IU/1); this woman had received HPV77-DE5 10 years previously and was revaccinated with RA27/3 in 1981 as she had no antibodies detectable by single radial haemolysis and had a radioimmunoassay titre of $80(<15000 \mathrm{IU} / \mathrm{l})$. Although in 1983 she had a radioimmunoassay titre of 320 , single radial haemolysis showed that her antibodies had again declined to undetectable values. Although antibodies detectable by radioimmunoassay but not by single radial haemolysis may be associated with protection, it has previously been shown that viraemia may occur in patients with antibody values below $15000 \mathrm{IU} / 1 .{ }^{2}{ }^{5}$ Until the antibodies conferring immunity have been more accurately identified, it is generally advisable to offer vaccination to women with antibody values below $15000 \mathrm{IU} / \mathrm{l}$ as determined by single radial haemolysis.

Although these results are encouraging, they should not detract from the importance of continued long term surveillance in order to determine persistence of antibody, booster antibody responses, and outcome of pregnancies among women who have been given different rubella vaccines and may have been exposed to rubella. Geometric mean titres should be interpreted with caution, since they may not merely reflect the magnitude of the immune response to vaccine but may also be a reflection of booster antibody responses due to exposure to rubella in the community. We aim to collect further blood samples from the volunteers in this study in order to test the frequency of this phenomenon.

${ }^{1}$ O'Shea S, Best JM, Banatvala JE, Marshall WC, Dudgeon JA. Rubella vaccination: persistence of antibodies for up to 16 years. Br Med $\mathcal{J}$ $1982 ; 285: 253-5$.

2 O'Shea S, Best JM, Banatvala JE. Viremia, virus excretion, and antibody responses after challenge in volunteers with low levels of antibody to rubella virus. $\mathcal{F}$ Infect Dis $1983 ; 143: 639-47$.

${ }^{3}$ Kurtz JB, Mortimer PP, Mortimer PR, Morgan-Capner P, Shafi MS, White GBB. Rubella antibody measured by radial haemolysis. Characteristics and performance of a simple screening method for use in diagnostic laboratories. $\mathcal{F}$ Hyg (Camb) 1980 ;84:213-22.

4 Best JM, Harcourt GC, Druce A, Palmer SJ, O'Shea S, Banatvala JE. Rubella immunity by four different techniques: results of challenge studies. F Med Virol 1980;5:239-47.

5 Balfour HH, Groth KE, Edelman CK, Amren DP, Best JM, Banatvala JE. Rubella viraemia and antibody responses after rubella vaccination and reimmunisation. Lancet 1981 ; i :1078-80.

(Accepted 6 fanuary 1984)

Department of Virology, St Thomas's Hospital and Medical School, London SE1 7EH

SIOBHAN O'SHEA, MIBIOL, research assistant

JENNIFER M BEST, PHD, MRCPATH, senior lecturer

J E BANATVALA, MD, FRCPATH, professor of clinical virology

The Hospital for Sick Children, Great Ormond Street, London WC1 W C MARSHALL, MD, FRACP, consultant paediatrician. (Dr Marshall died on 24 October 1983)

J A DUDGEON, MD, FRCP, emeritus professor of microbiology

Correspondence to: Professor J E Banatvala. 